KatARZyna ŁASAK

\title{
Individual Communications Against Poland Before the Human Rights Committee: a Review and Tentative Conclusions
}

\section{Introduction}

The International Covenant on Civil and Political Rights (the Covenant) was adopted on 16 December $1966 .{ }^{1}$ Poland became a party thereto on 18 June $1977 .{ }^{2}$ The statement of consent to be bound by the Covenant did not contain reservations. However, Poland made other declarations of will, influencing the direction of interpretation and application of the Covenant, including opposition to the reservations made by Mauritania and Pakistan. ${ }^{3}$

The ratification imposes on Poland the obligation to submit to the Human Rights Committee (the Committee) reports on the implementation of the Covenant. On 25 September 1990 the Republic of Poland recognized the competence of the Committee to examine communications by other parties to the Covenant concerning any possible violations of the provisions thereof by the Polish State (Article 41). No State has complained about Poland under this procedure.

Poland has been a party to the Optional Protocol to the International Covenant on Civil and Political Rights of 16 December 1966 (the Protocol) ${ }^{4}$ since 7 February 1992. Thus, the Polish State has recognized the competence of the Committee to accept and examine the communications from individuals (Article 1). ${ }^{5}$ The Republic of Poland decided to accede to the Protocol, with the reservation excluding the procedure provided for in Article 5 § $2(\mathrm{a})$ thereof, if the matter has already been examined under another procedure of international investigation. ${ }^{6}$

1999 United Nations Treaty Series (UNTS) 1971, I-14668.

2 Dz.U. of 1977 no. 38 item 167.

3 https://treaties.un.org/Pages/ViewDetails.aspx?src=TREATY\&mtdsg_no=IV-4\&chapter= 4\&clang=_en\#EndDec [access: 30.03.2017].

4 Dz.U.1992 no. 23 item 80; 999 UNTS 171: A-14668.

5 http://indicators.ohchr.org/ [access: 22.10.2016].

6 Dz.U. 1992 no. 23 item 80. 
As of the day of the $31^{\text {st }}$ March, 2017, the Committee has received 11 communications submitted pursuant to Article 1 of the Protocol.

In two cases, namely those of Jan Piwowarczyk ${ }^{7}$ and Mirosław Getke, ${ }^{8}$ the Committee has concluded the proceedings in the case. In the first case, there has been a discontinuation of the proceedings as a result of the inability to contact the author of the communication. ${ }^{9}$ The fact that there was no answer by the lawyer of the applicant in the latter case, despite the repeated attempts by the Committee, put an end to the proceedings. ${ }^{10}$

Inadmissibility decisions have been made in five cases. These were the communications addressed to the Committee by Janusz Kolanowski, ${ }^{11}$ Eugeniusz Kurkowski, ${ }^{12}$ Zdzisław Bator, ${ }^{13}$ Barbara Wdowiak ${ }^{14}$ and M.G. ${ }^{15}$

In another three cases, the Committee ruled on their merits. Only in one of them did the Committee find a violation. That was the case of Bożena Fijałkowska. ${ }^{16}$ In the cases of Wiesław Kall ${ }^{17}$ and Tatyana Rastorgueva ${ }^{18}$ the Committee did not find a violation of the rights of the applicants.

Taking into account that this year, 2017, is the fortieth anniversary of the Covenant entering into force for Poland, and twenty five years since Poland agreed to be bound by the Protocol, it would be interesting to have a look at the Polish applications, not only in terms of statistics but also as a special measure for the implementation of the human rights laid down in the treaties indicated.

\section{The decisions on inadmissibility}

\section{Janusz Kolanowski}

Janusz Kolanowski (J.K.) claimed that Article $14 \S 1$ and Article 26 of the Covenant were violated because he had been refused the access to the court, on the basis that the

7 No. $955 / 2000$.

8 No. $1025 / 2001$.

9 Report of the Human Rights Committee, Volume I, Seventy-ninth session (20 October7 November 2003), Eightieth session (15 March-2 April 2004), Eighty-first session (5-30 July 2004), United Nations, New York 2004, § 87.

10 Report of the Human Rights Committee, vol. I, Eighty-eight session (16 October-3 November 2006), Eighty-ninth session (12-30 March 2007), Ninetieth session (9-27 July 2007), United Nations, New York 2007, § 98.

11 Human Rights Committee (HCR), Kolanowski v. Poland, no. 837/1998, Date of decision on admissibility: 6 August 2003.

12 HCR, Kurkowski v. Poland, no. 872/1999, Date of decision on admissibility: 18 March 2003.

13 HCR, Bator v. Poland, no. 1037/2001, Date of decision on admissibility: 22 July 2005.

14 HCR, Wdowiak v. Poland, no. 1446/2006, Date of decision on admissibility: 31 October 2006.

15 HCR, M.G. v. Poland, no. 2183/2012, Date of decision on admissibility: 23 July 2015.

16 HCR, Fijatkowska v. Poland, no. 1061/2002, Date of adoption of views: 26 July 2005.

17 HCR, Kall v. Poland, no. 552/1993, Date of adoption of views: 14 July 1997.

18 HCR, Rastorgueva v. Poland, no. 1517/2006, Date of adoption of views: 28 March 2011. 
refusal to promote him to the aspirant rank in the Police was not considered an administrative decision and therefore it was not subject to the judicial review of the High Administrative Court (HAC).

According to the applicant, his communication on the refusal of appointment and nondelivery of an administrative decision involved a determination of his rights and obligations in a suit at law, since Article $14 \S 1$ should be interpreted broadly in that respect. What is more, in his opinion, the bias of the judges of the HAC and the fact that he had been deprived of the possibility to lodge an extraordinary appeal, either through the Minister of Justice or through the Ombudsman, who had failed to process his request in a timely manner, were further violations of Article $14 \S 1$.

The author of the communication claimed that the issuance of an administrative decision was required in similar situations, such as in cases of lowering of the military ranks of the professional soldiers of the Polish Army or when a university granted an academic degree. Since soldiers and academic candidates can appeal such decisions before the court, the author claimed that the fact that such a remedy was not available to him constituted a violation of Article 26.

The applicant argued that he had exhausted domestic remedies available, and that the same matter was not examined under another procedure of international investigation.

The Committee ascertained that pursuant to Article $5 \S 1$ (a) of the Protocol, the case of J.K. was not being examined under another procedure of international investigation or settlement, and that pursuant to Article 5 \$ (a) the applicant had exhausted all the remedies available. The standpoint of the applicant in the respect indicated was not contested by the Polish State.

In the case of J.K., the defending State Party claimed that the communication should be inadmissible ratione temporis, as well as due to the lack of substantiation of an alleged violation of Article $14 \S 1$ and Article 26 of the Covenant. The Committee agreed with the opinion of the State Party and considered the communication inadmissible under Article 2 and Article 3 of the Protocol.

According to established jurisprudence of the Committee, alleged violations of the Covenant are not recognized if they happened before the Protocol entered into force for the State to which they were addressed. The Committee decided in this manner, for example, in the case of the policeman from Togo who had been allegedly wrongfully dismissed from service, and who had lodged 40 complaints in total to the Togolese authorities about the situation in question, and received no reply. ${ }^{19}$

Situations where possible violations of the Covenant that begun before and continue after the Protocol for a particular State enters into force constitute exceptions. Therefore, when the alleged accusations of torture and the ill-treatment of a prisoner, related to

19 HRC, Kéténguéré Ackla v. Togo, no. 505/1992, Date of adoption of views: 25 March 1996. 
both the period before the Protocol entered into force in Venezuela and after this date, the Committee found the communication admissible ratione temporis. ${ }^{20}$

The Protocol entered into force for Poland on 7 February 1992. The applicant J.K. had requested the Chief Commander of the Police to appoint him to the rank of aspirant officer of the Police on 7 January 1991. The proceedings in his case at the domestic forum ended on 2 September 1996, when the Ombudsman rejected to submit an extraordinary appeal for the second time and warned that his accusations against the judges of the HAC might be interpreted as constituting a criminal offence.

There is no doubt that the proceedings in the case of J.K. before the domestic authorities were started before the Protocol entered into force in Poland. The proceedings were continued, upon the initiative of the applicant, after this fact. However, in the opinion of the Committee the proceedings did not constitute any potential violation of the Covenant. Consequently, the Committee could consider the communication inadmissible ratione temporis.

As far as the claim of violation of Article $14 \S 1$ of the Covenant is concerned, its essence was boiled down to the applicant's efforts to contest the decision that refused to promote him to the rank of officer. The applicant was not dismissed and neither did he apply for any specific post where holding such a rank would be required. As was pointed out by the committee, in this aspect his case should be distinguished from the situation of the head of the emergency management centre in Nancy who had been dismissed due to his alleged incompetence, and who also complained about the lack of an effective remedy. ${ }^{21}$ The Committee recalled that the right to a fair and public hearing of a case by the court is a concept based on the nature of the rights and obligations claimed, rather than on the status of the parties to the proceedings. According to the Committee, the procedures initiated by J.K., which were aimed at contesting the decision that rejected his request for a promotion to the rank of officer in the Polish Police, were not proceedings relating to the determination of his rights and obligations in the meaning of Article $14 \S 1$. Thus, this part of the application was held to be incompatible with the wording of the Covenant's provision referred to and was found inadmissible under Article 3 of the Protocol.

In relation to the violation of Article 26 of the Covenant, the Committee only stated that J.K. had failed to substantiate, for the purposes of admissibility, any potential violation. In such cases, communications are considered inadmissible under Article 2 of the Protocol.

In order to substantiate communications, the facts of the case should be presented in a manner that enables the Committee to assess them. The applicant should demonstrate

20 HCR, Katy Solórzano de Peña and Luis Alberto Solórzano v. Venezuela, no. 156/1983, Date of adoption of views: 28 March 1996.

21 HCR, Casanovas v. France, no. 440/1991, Date of decision on admissibility: 7 July 1993. 
that he/she has been a victim of an alleged violation of their rights under the Covenant. If the facts and arguments submitted illustrate the case insufficiently, or they cannot be verified, or they do not indicate a violation of any of the rights provided for by the Covenant, the Committee does not continue the examination of the case in this particular respect. ${ }^{22}$ For example, in J.M. v. Jamaica, the fact that the applicant failed to submit evidence (e.g. a birth certificate) as proof that he was the citizen of Jamaica entailed that his claim of deprivation of the right to enter his home country was found inadmissible. ${ }^{23}$ In Kolanowski v. Poland, the claims by the applicant were not substantiated by a comparison with the legal situation of a professional soldier with a lowered rank, which was always the case under an administrative decision pursuant to $\S 1$ of the Ordinance of the Minister of Defence of 27 July 1992, and the internal decisions in relation to policemen under the Police Act, taking into consideration the application of $\$ 1$ to extraordinary cases. What is more, it is impossible to compare the situation of obtaining an academic degree, which is made under an administrative decision, and being promoted to a higher rank in the Police service, due to different materiae.

\section{Eugeniusz Kurkowski}

From December 1976 until 1989, Eugeniusz Kurkowski (E.K.) held a post in the Civic Militia. In 1989 he was appointed the Chief of the Regional Office of Internal Affairs in Andrychów. On 31 July he was dismissed pursuant to the Protection of State Office Act of 6 April 1990, under which the secret police had been dissolved by transforming it into a new department.

In Ordinance of 21 May 1990 the Council of Ministers established the qualification procedures and the criteria for reinstatement at a new department of the dismissed officers. The reinstatement could take place only after a positive assessment by the regional qualifying commission was issued, or through an appeal to the Central Qualifying Commission in Warsaw. On 22 July 1990 the Qualifying Commission in Bielsko-Biała held that the author of the communication had not met the criteria for officers or civil employees of the Ministry of Internal Affairs. The Central Qualifying Commission confirmed that opinion on 5 September 1990 after the appeal submitted on 28 July 1990.

On 25 April 1995, the applicant requested that the Minister of Internal Affairs reverse the decision of the qualifying commissions and reinstate him in the Police. In the proceedings before the Committee, E.K. justified the delay in his appeal by explaining his poor health condition, which was only partially confirmed. On 25 May 1995, the Minister of Internal Affairs informed the applicant that he had no competence to change the decisions issued by the qualifying commissions or to employ anyone who had not

22 V., e.g., HCR, Larry James Pinkney v. Canada, no. 27/1978, Date of adoption of views: 29 October 1981.

23 HCR, J.M. v. Jamaica, no. 165/1984, Date of decision on admissibility: 26 March 1986. 
received their positive assessment. On 1 February 1996 the Minister of Internal Affairs upheld the previous opinion. The applicant submitted an appeal to the CAC. That Court held that it was not competent to examine the opinions issued by the qualifying commissions.

The author of the communication claimed that he was a victim of Poland' of Article 25(c) of the Covenant, since he had been dismissed from the Police by the Minister of Internal Affairs for being a member of the Polish United Workers' Party and holding leftist political views. What is more, the applicant claimed that the Minister of Internal Affairs had unjustly classified him as a member of the Security Police, when he had served in the police and had worn a uniform of its officer. The applicant argued that this violation should be considered together with the violation of Article $2 \S 1$ of the Covenant.

E.K. claimed that his right to access a court and the right to be heard by an independent and impartial court had been violated, since neither the question of his dismissal nor his retroactive classification as a Security Police agent could be reviewed by the court.

The Committee found that the conditions of admissibility of the communication under Article $5 \S 2$ of the Protocol had been met. The applicant had exhausted the domestic remedies available and his case was not being examined under another procedure of international investigation at that time.

On the other hand, the Polish State claimed that the communication was inadmissible ratione temporis, since the qualification proceedings for its author were ended on 5 September 1990, i.e. before the Protocol entered into force for Poland on 7 February 1992. The applicant claimed that the Covenant had been binding upon Poland since 1977, and although the Protocol had entered into force in Poland in 1992, he had taken no action against his dismissal until 1995, i.e. after the Protocol had entered into force.

The Committee noted that the author of the communication had been dismissed in 1990, under the law applicable at that time and that the same year he had submitted himself to the assessment of the qualification commissions in order to determine whether he satisfied the new statutory conditions of employment in the structures of the Ministry of Internal Affairs. The fact that he had not won his case in the proceedings started in 1995, after the Protocol entered into force, did not amount to a violation of the Covenant. The Committee did not conclude that the violation had occurred before the Protocol entered into force in Poland and continued after that. Accordingly, the Committee declared the communication inadmissible ratione temporis.

In accordance with established jurisprudence of the Committee, it cannot examine the communication if the alleged violations took place before the Protocol entered into force. ${ }^{24}$ The retroactive application of the Protocol could have occurred only if the viola-

24 HCR, Adimayo M. Aduayom, Sofianou T. Diasso and Yawo S. Dobou v. Togo, no. 422/1990, 423/1990 and 424/1990, Date of adoption of views: 12 July 1996. 
tion of the Covenant or its effects, had taken place since the time preceding the entry into force of the Protocol, and continued or still influenced the situation of the applicant. ${ }^{25}$ The applicant could have used the available remedies to alter his legal situation and he had done that. The proceedings in his case ended on 5 September 1990, thus before the Protocol entered into force in Poland. As a result, his case does not make it necessary to apply the Protocol retroactively.

\section{Zdzisław Bator}

Zdzisław Bator (Z.B.), an American and Polish citizen, set up a joint venture company in 1986 with his brother Waldemar Bator (W.B.), who was residing in Płock and had Polish citizenship. The company was named Capital Ltd., and its principal place of business was in Płock. The author of the communication held $81 \%$ of the shares in the Company and W.B. 19\%. The applicant provided funding for the establishment of the Company, which W.B. operated. Although the applicant resided in the USA, he travelled to Poland a few times a year and assisted in managing the business.

In 1994 the applicant discovered that allegedly W.B. and his wife were embezzling money from the Company. The author of the communication spent a few months in Poland trying to save the Company. However, in 1995, he decided that the Company should be dissolved. On 6 November 1995, during the meeting with W.B., the author as the majority shareholder, passed a resolution on dissolution of the Company and appointed himself as a liquidator. W.B. voted against the applicant's candidature and threatened that he would take the steps to remove him from the position concerned.

The author of the communication took several steps aimed at the liquidation of the company's assets. On 18 December, W.B., filed with the District Court in Płock the first request to replace the applicant as liquidator. On 15 March 1996 the District Court in Płock, at the closed hearing, decided that W.B. should replace the applicant in the post of liquidator. In the reasoning, the judge held that the author of the communication had failed to register the liquidation before 3 January 1996 and that his residence in the USA made him less capable of acting as liquidator (either personally or through his representatives). The applicant claimed that neither he nor his lawyer had been notified of the date and place of the hearing, and consequently, nobody was able to contest W.B.'s request.

Pursuant to the above ruling, the name of the applicant had been immediately deleted from the Commercial Register and the details of W.B. were entered there. On 27 May 1996, the decision of 15 March 1996 was reversed, since the judge had exceeded the authority by entering W.B. as liquidator into the Commercial Register. On 27 October 1996, an appeal by W.B. was dismissed and the applicant was entered into the Commercial Register as liquidator.

25 HCR, Joseph Frank Adam v. the Czech Republic, no. 586/1994, Date of adoption of views: 23 July 1996. 
On 11 July 1997, the same judge of the District Court in Płock heard another request by W.B. for replacing the applicant as liquidator. The applicant was not represented due to failure to notify him. The case was decided in favour of W.B. and the reasons were the same as in the judgment of 15 March 1996. On 30 October 1997, the Regional Court reversed the judgment of 11 July 1997 due to the failure to respect the principle of equality of arms and referred the case to the court of the first instance for reconsideration.

As the applicant was ill and not able to travel and his lawyer could not represent him on the date of reconsidering the case, the applicant applied for the case to be adjourned. According to the applicant, his request was delivered to the Court on the day of the hearing at 8.00 and was not taken into consideration. The District Court in Płock, ${ }^{26}$ this time in a different formation, ruled in favour of W.B. for the same reasons as in the previous ruling. All appeal attempts were unsuccessful.

The applicant claimed that he was a victim of Poland's violation of Articles 2 and 14 of the Covenant, since his case had not received a fair hearing by an independent and impartial court and thus, he could not defend himself properly against repeated attempts to dismiss him as liquidator.

When responding to the applicant's allegation that he did not receive a fair hearing of the case, the Committee observed that it related primarily to the evaluation of the facts and evidence by the courts. The Committee recalled the principle of its jurisprudence that it is the competence of the courts of the States and not of the Committee to evaluate the facts and evidence in individual cases, unless the courts' decisions are manifestly arbitrary or amount to denial of justice. The Committee noted that the Polish courts had considered the complaints by the applicant and they found none of the defects mentioned. Therefore, the Committee held that this part of the communication, as unfounded, was inadmissible under Article 2 of the Protocol.

In relation to the claim that the courts examining the applicant's case were neither independent nor impartial, the Committee noted that the applicant had never raised that issue in a domestic forum. Accordingly, it was inadmissible, since the author had not exhausted the remedies available. Eventually, the communication was declared inadmissible under Article 2 of the Protocol.

\section{Barbara Wdowiak}

In 1995 the applicant filed an application at the District Court in Kozienice seeking restitution of a small part of property to which, as she claimed, she was entitled. On 28 June 1995, the Court rejected her application for lack of evidence. In March 1998 new facts in the case were discovered, and the author filed a cassation appeal with the Regional Court in Radom on 9 August 1999, seeking to have her case reconsidered.

26 However, the judgment included several elements in the reasons, and held that the claimant had neglected the duties of liquidator. 
On 13 August 1999, the Regional Court in Radom dismissed her cassation appeal on the basis that the appeal must be prepared and filed by a qualified lawyer.

The author of the communication appealed the decision of the Radom Regional Court to the Supreme Court, which dismissed it, explaining that the cassation appeal must be prepared by a qualified lawyer or a legal counsel only.

Barabara Wdowiak (B.W.) explained that she could not afford to pay a lawyer to represent her and she had been refused a court appointed lawyer. The applicant also claimed that she had notified the Supreme Court of her difficult financial situation.

On 26 April 2000, B.W. submitted an application to the European Court of $\mathrm{Hu}-$ man Rights (the EHCR), setting out the above-mentioned facts therein. On 11 October 2000, that Court found her application inadmissible, on the grounds that she had not exhausted the available domestic remedies.

In the communication addressed to the Committee, the author claimed that she had been deprived of the right to a fair hearing of her rights in a suit of law, which is a violation of Article $14 \S 1$ of the Covenant.

The foreground criterion of admissibility, in the light of the facts presented, was that resulting from Article 5 \2(a) of the Protocol, providing that the Committee shall not examine any communication unless it establishes whether the same matter is not being examined under another procedure of international investigation or settlement, since the applicant had submitted a similar complaint to the European Court of Human Rights.

In this regard, it was necessary to establish that when Poland acceded to the Protocol it made the above-mentioned reservation to Article 5 § 2(a) of the Protocol. Therefore, the Committee had to consider whether the decision of the EHCR on the admissibility of the application by B.W. resulted from the examination of the same matter which had been submitted to the Committee.

In the Committee's jurisprudence it is held that an inadmissibility decision which entailed at least implicit consideration of the merits of a case amounts to an examination for the purpose of Article $5 \S 2(\mathrm{a})$ of the Protocol, whereas the Committee claims that finding inadmissibility for purely procedural reasons, without addressing the merits of a case, does not amount to examination of the case for the purpose of admissibility of the communication by the Committee. ${ }^{27}$

In the opinion of the Committee, the decision of the EHCR was strictly procedural in nature, finding only that the author had not exhausted the domestic remedies available. Accordingly, the Committee held that the matter submitted had not been examined by another procedure of international investigation or settlement.

The above conclusions required the examination of another admissibility criterion that was essential for the case of B.W., namely exhaustion of domestic remedies. An un-

27 HCR, Luis Bertelli Gálvez v. Spain, no. 1389/2005, Date of decision on admissibility: 25 July 2005. 
disputed fact was that the applicant has not complied with the formal requirements for filing a cassation appeal provided for in Polish law. It is equally important that she could not do so due to lack of financial means. In such cases domestic law allows for a request by a party to appoint a lawyer ex officio. It is examined by the court with which the cassation appeal is made. In the case of B.W. this was the Radom Regional Court. Notifying the Supreme Court of a difficult financial situation does not meet the requirement specified in that manner. Thus, due to the failure to meet the formal requirements to lodge a cassation appeal, the applicant did not exhaust the domestic remedies available to defend her rights. For that reason the Committee found her communication inadmissible.

The case of B.W. was examined by two international authorities and their decision on admissibility was the same, for the same reasons. Submitting the communication to the Committee was preceded by the author lodging the application to the EHCR. The EHCR held that the applicant had not exhausted the domestic remedies available. The case was subsequently assessed in the same way by the Committee, which arrived at the same understanding of the admissibility condition.

The Supreme Court's decision indicated that inability to pay for the cost of legal assistance was not an exception to the requirement that an appeal should be filed by a qualified lawyer. However, that Court also noted that a difficult financial situation makes a person eligible for application for free legal assistance. However, it was evidentt from the case files that the applicant had not submitted a request seeking the appointment of a lawyer ex officio for the purpose of filing a cassation appeal.

The requirement that the cassation appeal must be filed by a qualified lawyer is designed to guarantee the high quality of appeals, and to protect the Supreme Court from a backlog of appeals that do not meet the basic formal and substantive requirements. Taking into account that in the civil proceedings the cassation appeal is the last ordinary appeal remedy, it should have due regard to the interests of the party. The requirement of the mandatory operation through a lawyer introduced by Polish legislation does not restrict the right of access to the court, since it is possible to apply for the costs of legal representation to be covered. The Committee has not contested the solution adopted by Polish law and in accordance with settled jurisprudence could not act differently other than to declare that the communication was inadmissible under Article 2 of the Protocol. $^{28}$

\section{M.G.}

M.G. claimed in his communication to the Committee that Poland had violated his rights under Articles 7, 9(5) and 10(1) of the Covenant.

28 HCR, Lionel Bochaton v. France, no. 1084/2002, Date of decision on admissibility: 1 April 2004. 
From 28 February to 8 October 2007 the author of the application served a prison sentence at one of the prisons located in Warsaw, after he had been found guilty of fraud by the Regional Court in Warsaw.

In his communication M.G. claimed to have been the victim of inhuman and humiliating treatment while serving his prison sentence, relating to the social and living conditions. The applicant shared a cell with five other inmates. The surface of the cell was only $1.9 \mathrm{~m}^{2}$ square meters per inmate, while the [standard] under domestic law was $3 \mathrm{~m}^{2}$ per person.

As there was only one window in the cell, it was not ventilated properly and the light from two bulbs was insufficient for reading or writing. The lack of a dedicated space for meals meant that the prisoners had to eat on their beds and therefore the bed linen was constantly dirty. Separating the toilet only by a curtain prevented any privacy.

In the prison, no criteria for the separation of the prisoners according to the type of offence committed had been applied and, accordingly, they were located together randomly. The other prisoners were convicted of much more serious crimes, such as murder or robbery. Some of the other inmates were addicted to drugs or alcohol and their behaviour, upbringing and culture amounted to torture for M.G.

The applicant claimed that he sent numerous complaints to the prison's administration, but he received no written reply. His "tutor" officer explained that similar conditions prevailed throughout the prison.

On 3 July 2007, M.G. complained to the District Court in Warsaw about the conditions in the cell and requested compensation amounting to PLN $450000 .{ }^{29}$ The District Court in Warsaw agreed that the rights of M.G had been violated, first of all due to the excessive cell-occupation density, which according to the judgment by the Constitutional Court of 2008, could constitute inhuman treatment and the cumulative case elements could amount to torture.

The District Court in Warsaw, in a judgment of 29 October 2008, ordered that the Director of the Detention Centre where the applicant served imprisonment should address a written statement to him, acknowledging that there had been a violation of his human rights and making a commitment that similar violations would not happen in the future. Having assessed the duration of detention and the conditions of serving it, as well as the health condition of the applicant and his rights, the District Court in Warsaw held that the statement had constituted sufficient compensation and rejected his financial claims.

On 24 November 2008, M.G. appealed to the Regional Court in Warsaw. On 16 April 2010, the Appeal Court also found that the statement ordered by the judgment of the first instance court was a sufficient form of remedy in the case of M.G.

29 Approximately 120,000 Euros as at 3 July 2007. Source: National Bank of Poland, www.nbp.pl. 
On 3 February 2011, the Director of the Detention Centre, following the judgment issued by the District Court in Warsaw, addressed a statement to the applicant in accordance with the content of that Court's ruling.

M.G. raised in the communication that due to difficulties related to lodging a cassation appeal to the Supreme Court (compulsory preparation and submission by a qualified lawyer), he had resigned from that option and claimed that he had exhausted all the available domestic remedies.

By a note of 15 December 2014, Poland notified the Committee that on 24 May 2010 the applicant had filed an application to the EHCR concerning the conditions of his detention in Warsaw between 28 February and 8 October 2007. That fact was communicated to the Polish State on 6 October 2014.

On 16 February 2015, the applicant sent to the Committee his letter to the EHCR, dated the same day, in which he asked the EHCR to remove his application from the list of applications. M.G. asked the Committee to consider his case.

On 27 February 2015, the Registry of the EHCR confirmed that the case of M.G. was still pending.

Therefore, similarly to the case of B.W., the admissibility of the communication by M.G should have been assessed under Article $5 \S 2$ (a) of the Protocol. In this case, the Committee had no doubts that, contrary to the assurances of the applicant, his matter was being already examined under another procedure of international investigation or settlement. Consequently, the communication by M.G. was found inadmissible.

The interpretation of the principle resulting from Article $5 \S 2(\mathrm{a})$ of the Protocol in cases similar to that of M.G. poses no particular difficulties. ${ }^{30}$ It is well-established in the jurisprudence of the Committee and is applied almost automatically. ${ }^{31}$ Possible doubts can result from the initial evaluation by the parties, and often by the Committee itself, of the actual facts of the case. In such situations, in order to avoid any error in judgment, the Committee, under the rules of procedure, may always ask the parties to supplement information or issue a request in that respect to an authority which allegedly was, or currently is, examining the case. For example, in one case, the State argued that the proceedings before the Asian Development Bank met the criterion under Article 5 § (a) of the Protocol. Although it was not related to the rights derived from the Covenant, the Committee considered the communication in this regard admissible. ${ }^{32}$ The exchange of letters between the Committee and the parties to the proceedings and the EHCR was enough also in the case of M.G. to decide as to its admissibility.

30 HCR, D.F. v. Sweden, no. 183/1984, Date of decision on admissibility: 26 March 1985.

31 HCR, Dagmar Urbanetz Linderholm v. Croatia, no.744/1997, Date of decision on admissibility: 23 July 1993.

32 HCR, Susila Malani Dahanayake and 41 other Sri Lankan Citizens v. Sri Lanka, no. 1331/2004, Date of decision on admissibility: 25 July 2006. 


\section{The views}

\section{Wiesław Kall}

The author of the communication served in the Civic Militia in various positions. In the years from 1982 to 1990 , he served as a senior inspector at the political and educational section as a cadre officer. The author emphasized that the Civic Militia was not identical with the Security Police. On 2 July 1990, he was retroactively reclassified as a Security Police officer and on 31 July 1990 dismissed under the 1990 Protection of State Office Act, which dissolved the Security Police and established a new department.

Wiesław Kall (W.K.) appealed the decision of the Provincial Qualifying Committee in Częstochowa to the Central Qualifying Committee in Warsaw, which repealed it on 21 September 1990, finding that the author could apply for employment at the Ministry of Internal Affairs.

The author's application for employment at the Police in Częstochowa was rejected on 24 October 1990. W.K. wrote a letter to the Minister of Internal Affairs on 11 March 1991. The Minister, acting under Regulation no. 53 of 2 July 1990 noted that the officers who had performed services at the Political and Educational Board were considered to be members of the Security Police. Therefore, the applicant was dismissed lawfully, following the reorganisation of the Ministry of Internal Affairs' structures.

On 16 December 1991, the applicant applied to the HAC alleging unjustified dismiss$\mathrm{al}$ and an error in the verification procedure. That Court noted that it was not competent to examine the opinions of the qualifying committees.

In the communication to the Committee, W.K. argued that he had been dismissed without justification. The verification procedure prevented him from access to employment in the public service only because of his political opinions and the fact he was a member of the Polish United Workers' Party. In the opinion of the applicant, this situation constituted discrimination within the meaning of Article 25(c) of the Covenant.

On 5 July 1995, the Committee declared the communication admissible. The State Party tried to challenge that decision unsuccessfully. The Committee accepted neither the arguments concerning the failure to exhaust domestic remedies nor the lack of $r a-$ tione temporis competence in the case. The only clearly indicated substantiation for the position of the Committee was taking into account the reasons of the applicant relating to the exhaustion of the domestic remedies, namely that his insufficient legal awareness had caused him to appeal to the HAC against the opinion by the Central Qualifying Commission in Warsaw, instead of appealing the decision on the refusal of employment. In fact, the applicant had never, before any authority, challenged that decision. The letter to the Minister of Internal Affairs and the complaint to the HAC were not remedies in this case. 
The applicant should have brought a complaint to the Chief Commander of the Police, and then, if it was necessary, to the HAC. The author of the communication had 14 days to appeal to a higher court concerning the refusal of his employment. In the light of his failure to do so, the decision of 24 October 1990 became final. At that time, Poland was not yet bound by the Protocol. In accordance with established jurisprudence in such situations, the Committee declares the inadmissibility of the communication ratione temporis. ${ }^{33}$ However, the Committee acknowlegded the possibility to hear the case of W.K. despite the fact that it had to treat the issues raised as a continuing violation, i.e. affirmation by an act or clear implication of the previous violations of the State Party. ${ }^{34} \mathrm{It}$ should be assumed that the Committee identified the negative assessment of the applicant with his not being employed in the Police. The failure to separate those two events enabled them to be treated as subsequent sequences of one and the same case continued after Protocol entered into force for Poland. Otherwise, the Committee would have to declare the communication inadmissible ratione temporis. ${ }^{35}$

The above reasoning imposes on the Committee the obligation to assess the merits of the case, namely the examination of whether the verification procedure and then the refusal of employment in the Police violated the applicant's rights laid down in Article 25(c) of the Covenant.

The Committee noted that the termination of the applicant's employment had resulted from the dissolution of the Security Police under the Protection of State Office Act. As a result of the Security Police's dissolution, the posts of all members thereof were also abolished, without any differentiation.

The Committee, when considering the complaints relating to the verification procedure, noted that on appeal the applicant had been found eligible for a post in the Police. Therefore, the facts of the case demonstrate that the applicant had not been precluded from access to public service.

The Committee also referred to the problem of whether the refusal of employment in the Police constituted sufficient evidence to conclude that it was because of the political opinions of the communication's author, or whether it was a consequence of the limited number of posts available, as was argued by the State Party. Article 25(c) of the Covenant does not guarantee employment in public service to each citizen, but rather access to such employment on the general terms of equality. In the Committee's opinion, information provided in the case did not imply that this right was violated.

It should be noted that W.K. was dismissed from the police service ex lege. The Security Police was dissolved following a resolution of Parliament and subsequently those

33 HCR, Samuel Lichtensztejn v. Uruguay, no. 77/1980, Date of adoption of views: 15 July 1999. 34 HCR, E. and A.K. v. Hungary, no. 520/1992, Date of decision on admissibility: 7 April 1994. 35 HCR, R.A.V.N. et al. v. Argentina, no. 343, 344 and 345/1988, Date of decision on admissibility: 26 March 1990. 
employed there lost their jobs. The effects of the reorganization of the Ministry of Internal Affairs in this regard concerned all the members of the services under liquidation, not just the applicant. The regulation by the Minister of Internal Affairs, questioned in the course of the proceedings before the Committee, had been issued on the basis of the statutory delegation and only provided details to its provisions, pointing out what posts were classified as belonging to the Security Police. It is therefore difficult to accept that the applicant was retroactively reclassified, as was claimed by him and the Committee.

The applicant was able to challenge and did challenge the decision on ineligibility to serve in the Police, and the Committee agreed to that. However, the positive opinion of the appeal verification committee did not amount to an obligation to employ the applicant in the Police. The employment of any person in any industry is determined by a number of factors: first and foremost the current needs of an employer, and then the qualifications required from the applicant for a job.

Article 25(c) of the Covenant is to protect the organizational structure of the State against its appropriation by one or more groups which enjoy a special status. ${ }^{36}$ Consequently, the State must, as the Polish Government rightly raised, be able to establish criteria for the employment of citizens in public service. The work of a police officer does not exclusively require features that should be held by each employee. This is service to the State and the inhabitants thereof, which implies having specific moral values. The Security Police has been dissolved due to its total degradation, also in the ethical and political terms.

Notwithstanding the favourable opinion by the Central Qualifying Commission, the Chief Commander of the Police in Częstochowa was in a position to not consider the applicant as deserving employment in the new services or, due to the limited number of vacancies, he could prefer to give priority in employment to persons without his professional origins. However, it was not possible to assess the situation since W.K. had not tried to challenge that decision. Article 25(c) of the Covenant, in any event, does not guarantee employment in the Police. However, the provision of that Article requires States to establish the transparent guarantess, in particular of a procedural nature, of equal access to the public service, including the Police. They had been established in Polish law and it was up to the applicant whether they should be used or not.

\section{Bożena Fijałkowska}

The applicant had been suffering from schizophrenia since 1986. On 12 February 1998, Bożena Fijałkowska (B.F.) was committed to compulsory treatment at the Provincial Psychiatric Therapeutic Centre in Toruń. She was committed to this psychiatric institu-

36 HCR, CCPR General Comment no. 25: Article 25 (Participation in Public Affairs and the Right to Vote), The Right to Participate in Public Affairs, Voting Rights and the Right of Equal Access to Public Service, 12 July 1996, §§ 23-24. 
tion under the decision of the District Court in Torun of 5 February 1998, under Article 29 of the Law on Psychiatric Health Protection.

On 29 April 1998, the applicant was able to leave the psychiatric institution and continue the treatment as an outpatient. This was completed on 22 July 1998.

On 1 June 1998, B.F. went to the Torun District Court registry office to familiarise herself with her case files and obtain a copy of the transcript of the court hearing and the decision of 5 February 1998. The applicant received a copy of the judicial decision on 18 June 1998. On 24 June 1998, she appealed the decision of 5 February 1998 issued by the Toruń District Court. On 26 June 1998, the Regional Court in Torun dismissed her appeal since she had missed the statutory deadline for submitting it.

On 1 July 1998, B.F. requested that the Regional Court in Torun establish a new time limit for lodging an appeal. On 16 September 1998, the Regional Court in Torun refused the request submitted by the applicant. B.F. tried to challenge that decision, unsuccessfully.

On 20 October 1998, the applicant was assigned legal assistance in order to prepare her cassation appeal to the Supreme Court. On 21 April 1999, the Supreme Court rejected the cassation appeal.

On 1 September 1999, the Supreme Court rejected, due to lack of competence, the applicant's request for a review of the constitutionality of the Law on Psychiatric Health Protection.

In the opinion of the B.F., her committal to a psychiatric institution, without her consent, violated Article 7 of the Covenant. She also claimed that treating her at the psychiatric institution amounted to cruel, inhuman or degrading treatment.

In the case of B.F. the issue of admissibility decision seems particularly interesting. The Polish Government argued that the communication was inadmissible due to her failure to exhaust domestic remedies. In its opinion, the applicant should have filed a constitutional complaint pursuant to Article 79 of the Constitution of 2 April 1997. The claim by the applicant, that the compulsory psychiatric treatment had been cruel, inhuman and degrading treatment, could be examined in the context of a violation of her rights provided for in Articles 39, 40 and 41 of the Constitution. Such a complaint would have verified the constitutionality of Article 29 of the Law on Psychiatric Health Protection.

Not only did the Committee not take into consideration the position of Poland in relation to the failure to exhaust the remedies available, but it did not refer to this at all. However, the Committee noted that the applicant provided no evidence for her claims that Article 7 of the Covenant had been violated, and only developed and reiterated the original version thereof in further documents. In the Committee's opinion, those claims were inadmissible under Article 2 of the Protocol since they had not been duly substantiated. In all probability, the direction of the communication's admissibility assessment, 
under Article 7 of the Covenant, selected by the Committee, was less complicated in comparison with the examination of whether the constitutional complaint should have been issued before submitting the communication. However, it is interesting that the equivalence of the legal basis of inadmissibility and that raised by the defendant party was maintained.

Although the Committee decided that the original claims had been inadmissible, it found such issues in the case which, in its opinion, should require the continuation of the proceedings. In the opinion of the Committee the circumstances, under which the decision of the applicant's committal to compulsory treatment [at a psychiatric institution] had been made, and in particular the fact that there was no legal representation and that she did not receive a copy of the decision on committal until 18 June 1998, more than four months after it had been issued, and after the expiry of the deadline to lodge an appeal, may raise problems under Article 9 and Article 14 of the Covenant.

On 9 March 2004, the Committee held that the communication was admissible under Articles 9 and 14 of the Covenant. The State Party was asked to submit comments as to whether the applicant's detention had been made in accordance with the procedure established by the law in the meaning of Article 9 of the Covenant, and whether failure to provide legal representation and to provide the author with a copy of the decision on committal in due time amounted to arbitrary detention, contrary to that Article. The Committee also requested that the State Party comment on any possible violation of Article 14 of the Covenant in the applicant's case.

As provided for in Article $5 \S 1$ of the Protocol, the Committee examined the case of the applicant after obtaining information from all the parties to the dispute.

Committing an individual to a psychiatric institution against the patient's will, as in the case of the applicant, amounts to deprivation of liberty in the meaning of Article $9^{37}$, which was not questioned by the Polish authorities. Poland indicated particular provisions of the Law on Psychiatric Health Protection of 1994, under which the court had issued a decision on the compulsory committal of the applicant to the psychiatric institution $^{38}$. Therefore, the Committee assumed that the applicant had been committed compulsorily to the Mental Health Centre in Torun under the rules and procedures, and in accordance with the law.

In relation to the possibly arbitrary nature of the applicant's compulsory psychiatric treatment, the Committee did not agree with the opinion of the Polish Government that the deterioration of mental health and inability to meet her basic needs had not affected her legal capability. As to the State Party's argument that "mental illness cannot be equated to a lack of legal capacity," the Committee considered that confinement of an individual to a psychiatric institution amounted to an acknowledgement of the 37 HCR, A. v. New Zealand, no. 754/1997, Date of adoption of views: 15 July 1999. 38 Articles 22 and 29. 
individual's diminished capacity, legal or otherwise. The State has a particular obligation to protect the people vulnerable to their rights' infringement, including the mentally impaired. The applicant's diminished capacity to act could have affected her ability to participate in the proceedings in her case, and thus the court should have been able to ensure that she was duly represented. The Committee noted that the applicant could not be represented by her sister, as was suggested by the State Party, since she had requested for the committal decision to be issued. The Committee admitted that it might happen that an individual's mental health was so impaired that in order to avoid harm to the individual herself or other people, a committal decision, without providing due representation, might be unavoidable. In the applicant's case there were no such circumstances. Consequently, the Committee found that her compulsory committal to a psychiatric institution had been arbitrary in the meaning of Article $9 \S 1$ of the Covenant.

Further, the Committee noted that although a committal decision might be appealed to the court, the applicant who had not received the copy thereof and had never been represented by anyone during the proceedings, had to wait until she was released from the psychiatric institution and became aware of relevant information and, applying that information, submitted an appeal. The appeal was dismissed for formal reasons. In the view of the Committee, the applicant's right to challenge the decision on her detention was not provided effectively and constituted a violation of Article $9 \S 4$ of the Covenant.

Due to the finding of a violation of Article 9 \$s 1 and 4 of the Covenant, the Committee did not need to consider whether there had also been a violation of Article 14 of the Covenant.

Pursuant to the provisions of Article $2 \S 3(\mathrm{a})$ of the Covenant, the State Party was obliged to provide F.B. an effective remedy, including compensation, and to make such legislative changes which were necessary to avoid similar violations in the future.

It is not possible to disagree with the opinion of the Committee that a mental illness affects an individual's ability to act. However, it is a fact that neither Polish law, nor probably any other legal system, equates mental illness with the loss of legal capacity. Thus, due to the protection of the basic interests of an individual suffering from this type of illness, Polish law provides for a number of substantive and procedural security measures that do not allow, without an in-depth examination of the case, for declaring incapacitation, even partial,. An effect in the case of B.F. and others may be such that a person suffering from schizophrenia is considered, in the context of the ongoing legal proceedings, fully able to assess her situation. Probably the basis for the verification of the facts in such cases should be the opinion of an expert psychiatrist. Some elements of the case indicated that the applicant's behaviour was indeed conscious. However, it could equally result from afear of being placed in a psychiatric institution. In this sense, the applicant could properly assess the reality and resist the actions by the relevant services with the measures known to her. It is hard to blame the public authorities in the case of B.F. as 
they took effective and efficient action aimed at providing her with assistance by the compulsory treatment due to the deteriorating condition of her mental health. The court hearing her case had a duty of care relating to her rights. The assertion of the Committee, in the light of the circumstances of the case, that the applicant was not immediately provided with a copy of the committal decision in order for her to appeal it constitutes a violation of Article $9 \S \S 1$ and 4, and seems to be an excessively broad interpretation of the Covenant. Even if it was assumed that the court was competent to appoint the defence counsel for the applicant without her consent, it is doubtful whether she could understand the arguments and what was happening in the case at the moment when the decision on the compulsory treatment was made, and the consequences thereof, if the opinion of the Committee on her capacity for discernment had been accepted.

\section{Tatyana Rastorgueva}

The author of the communication is a citizen of Belarus. Tatyana Rastorgueva (T.R.) submitted the complaint on behalf of her nephew, Maxim Rastorguev (M.R.), also a citizen of Belarus, was serving a prison sentence in Poland.

On 18 March 2000, M.R. was detained by the Polish Border Guards at the border between Poland and Belarus, since he was wanted by the Polish Police. On 24 March 2000, M.R. was transported to Chełm, where he appeared before the court. He was informed that he was a suspect in an armed robbery and murder, and temporary detention was applied. On the same day, M.R. was interrogated by a prosecutor in the absence of a lawyer, but in the presence of an interpreter, as he did not speak Polish. During the preliminary investigation he was questioned several times without the presence of a defence counsel.

M.R. allegedly met the court appointed lawyer on 13 December 2000. The applicant claims that M.R. was not able to prepare his defence because there was no interpreter. M.R. claimed that the defence counsel met him two more times before the court proceedings started, on 8 February 2001 and 23 April 2001, also without an interpreter and only for a short period of time.

On 4 July 2001, the Regional Court in Lublin convicted M.R. of armed robbery and murder and sentenced him to 25 years' imprisonment. The defence counsel appealed without consulting M.R. On 20 December 2001, the Appeal Court in Lublin upheld the sentence of the first instance court. The lawyer of M.R. did not file a cassation appeal, arguing that the conditions required had not been met. Therefore, M.R. missed the deadline to file a cassation appeal. The cassation appeal was lodged by another lawyer. On 1 October 2002, the Supreme Court upheld the judgments of the lower instance courts.

The applicant claimed that M.R. had not been able to appeal against the violations of the Covenant, since appeals in Poland must be submitted by lawyers. The author claimed that the defence counsels acting in the case of M.R. had not raised the violations of the Covenant. Consequently, M.R. had not had access to effective remedies. 
In 2003 M.R. submitted an application to the EHCR. The author of the communication claimed that his case had been discontinued as the Registry of the Court could not contact M.R.

The author of the communication claimed that, as a result of detaining M.R. for six days without informing him of the charges, Poland had violated Article $9 \S 2$ of the Covenant. She claimed that for the same reason Article 7 of the Covenant had been violated. Since M.R. appeared before the court only after six days, she added that Article 9 $\S 3$ of the Covenant had been violated with respect to him.

Since M.R. had been questioned without the presence of a lawyer and his rare meetings with his lawyer had been short and without the presence of an interpreter, there was a violation of Article 14 § (b) of the Covenant in his case.

The applicant contended that the Polish courts had discriminated against M.R., on the grounds of nationality and, therefore, their decisions were wrong, which constituted a violation of Article $14 \S 1$ and 26 of the Covenant.

The Committee declared the claims relating to violations of Articles 7, $14 \S 1$ and 26 of the Covenant inadmissible, because they were not sufficiently substantiated under Article 2 of the Covenant. The Committee declared the communication under Article 9 $\S \S 1,2$ and 3, as well as Article 14 3(b) of the Covenant to be admissible.

On the basis of the documents submitted to the Committee, it could not be concluded that the lawyers of M.R. had not been able to represent him adequately, or that they had shown lack of professionalism in conducting his case. What is more, nothing indicated that the courts should have noted that the conduct of the defence counsels was contrary to the interests of the judiciary.

As to the claim of inability to prepare defence in the absence of an interpreter, the Committee referred to the comments by the State Party stating that an interpreter had been provided during the interrogations and court hearings. However, if M.R., as noted by the Committee, had perceived the facts differently during the hearings, he could have informed the courts examining his case on those defects to the proceedings. However, that did not happen even once.

The applicant argued that M.R. could not, due to the absence of an interpreter and the relevant legal assistance, raise claims against the violation of his rights under the Covenant. However, as it is apparent from the files of the case that M.R. twice sent letters to the prosecutor inviting him to come and visit him in prison. These letters were translated from Russian to Polish, so that they could be responded to. M.R. himself requested that the Supreme Court appoint a defence counsel in order to prepare a cassation appeal. Therefore, the argument that M.R. could not submit complaints, appeal or produce other applications relating to the proceedings in his case or violations of his rights under the Covenant, due to the language reasons, was considered unconvincing. 
The Committee concluded that the communication did not reveal a violation of the rights of M.R. as laid down by Article 9 § 1, 2 and 3 and Article 14 §(b) of the Covenant, and held them manifestly illfounded within the meaning of Article $5 \S 4$ of the Protocol.

It should be emphasized that although it is incumbent on the State party to provide effective legal aid representation in such situations as that of M.R, it is not for the Committee to determine how this should have been ensured, unless it is apparent that there was a miscarriage of justice. ${ }^{39}$

What is more, despite the applicant's allegations, the Committee did not find any irregularities in the behaviour of the defence counsel acting ex officio, on behalf of M.R., in both instances. ${ }^{40}$

Finally, it should be emphasized that the cassation appeal was submitted by the lawyer appointed by M.R. himself. The cassation appeal was rejected as there were no reasons to lodge it, a fact which M.R. had been notified of by his ex officio defence counsel. In accordance with the jurisprudence of the Committee, the State Party is not responsible for the actions of the defence counsel hired by the person concerned. ${ }^{41}$

\section{Conclusions}

Taking into consideration the duration of Poland's functioning in the system of the Covenant, the number of individual communications brought against Poland is small. In most cases, decisions on inadmissibility have been made. Where the Committee ruled on the merits of the case, it usually did not find a violation. Finally, if a violation was found, it covered a scope different from that which had been specified by the allegations included in the communication. Therefore, does the Polish State implement the provisions of the Covenant to a satisfactory extent, so that the individuals do not initiate proceedings before the Committee?

Only the ideal State of Plato could act impeccably towards individuals. However, this thesis could also be considered not fully accurate, if it is taken into account that he did not know the concept of human rights in the meaning of the Covenant.

Poland, as any other State, struggles with difficulties in the implementation of human rights, although in different areas, not only under the Covenant. Some of them are reflected in the communications lodged with the Committee under the Protocol. Certainly, there are those which relate to the issue of the proper administering of justice. However, it should be emphasized that not in all the cases did the requests of the applications deserve consideration.

39 HCR, Hensley Ricketts v. Jamaica, no. 667/1995, Date of adoption of views: 4 April 2002. 40 HCR, Campbell v. Jamaica, no. 618/1995, Date of adoption of views: 20 October 1998. 41 HCR, Griffin v. Spain, no. 493/1992, Date of adoption of views: 4 April 1995. 
It seems appropriate to treat even inadmissible communications as a signal to explore, from a broader perspective than the circumstances of one case, the problems raised in the content of these cases, in particular when it is repeated. Some of the applicants, prior to submitting communications to the Committee, had tried to assert their views before the EHCR. Doing so may be evidence of lack of relevant knowledge, but italso suggests the severity of certain phenomena which should not be neglected.

After all, individuals who are subject to the jurisdiction of the Polish State essentially make applications that apply the provisions of the Convention. This is for several reasons, the most important of which are as follows. The Convention is the most recognizable system of human rights protection, not only in the region. The treaty was drawn up according to the standards and aspirations of European societies and not the whole world. The Convention is constantly evolving and is developing at a pace that is unacceptable to the United Nations States. The applications are filed under the Convention with an authority that issues binding decisions, and not with an authority that makes decisions in the form of an opinion, as the Committee does. Important differences apply also to the manner of adjudicating on fair compensation and, possibly, damages.

Taking the above into consideration, it seems that Poland has no particular interest in remaining in the system of the Covenant due to the possibility of individuals submitting applications. In this context, even the essential similarities of the Convention and the Covenant in both the substantive and procedural terms argue in favour of this view. In none of these aspects does any group of people gain any outstanding protection under the Covenant.

\section{Literature}

Human Rights Committee, CCPR General Comment no. 25: Article 25 (Participation in Public Affairs and the Right to Vote), The Right to Participate in Public Affairs, Voting Rights and the Right of Equal Access to Public Service, 12 July 1996.

Report of the Human Rights Committee, vol. I, Seventy-ninth session (20 October7 November 2003), Eightieth session (15 March-2 April 2004), Eighty-first session (5-30 July 2004), United Nations, New York 2004.

Report of the Human Rights Committee, vol. I, Eighty-eight session (16 October-3 November 2006), Eighty-ninth session (12-30 March 2007), Ninetieth session (9-27 July 2007), United Nations, New York 2007.

A. v. New Zealand, no. 754/1997, Date of adoption of views: 15 July 1999.

Adimayo M. Aduayom, Sofianou T. Diasso and Yawo S. Dobou v. Togo, no. 422/1990, 423/1990 and 424/1990, Date of adoption of views: 12 July 1996.

Bator v. Poland, no. 1037/2001, Date of decision on admissibility: 22 July 2005. 
Campbell v. Jamaica, no. 618/1995, Date of adoption of views: 20 October 1998.

Casanovas v. France, no. 440/1991, Date of decision on admissibility: 7 July 1993.

Dagmar Urbanetz Linderholm v. Croatia, no. 744/1997, Date of decision on admissibility: 23 July 1993.

D.F. v. Sweden, no. 183/1984, Date of decision on admissibility: 26 March 1985.

E. and A.K. v. Hungary, no. 520/1992, Date of decision on admissibility: 7 April 1994.

Fijatkowska v. Poland, no. 1061/2002, Date of adoption of views: 26 July 2005.

Griffin v. Spain, no. 493/1992, Date of adoption of views: 4 April 1995.

Hensley Ricketts v. Jamaica, no. 667/1995, Date of adoption of views: 4 April 2002.

J.M. v. Jamaica, no. 165/1984, Date of decision on admissibility: 26 March 1986.

Joseph Frank Adam v. the Czech Republic, no. 586/1994, Date of adoption of views: 23 July 1996.

Kall v. Poland, no. 552/1993, Date of adoption of views: 14 July 1997.

Katy Solórzano de Peña and Luis Alberto Solórzano v. Venezuela, no. 156/1983, Date of adoption of views: 28 March 1996.

Kéténguéré Ackla v. Togo, no. 505/1992, Date of adoption of views: 25 March 1996.

Kolanowski v. Poland, no. 837/1998, Date of decision on admissibility: 6 August 2003.

Kurkowski v. Poland, no. 872/1999, Date of decision on admissibility: 18 March 2003.

Larry James Pinkney v. Canada, no. 27/1978, Date of adoption of views: 29 October 1981.

Lionel Bochaton v. France, no. 1084/2002, Date of decision on admissibility: 1 April 2004.

Luis Bertelli Gálvez v. Spain, no. 1389/2005, Date of decision on admissibility: 25 July 2005.

M.G. v. Poland, no. 2183/2012, Date of decision on admissibility: 23 July 2015.

R.A.V.N. et al. v. Argentina, no. 343, 344 and 345/1988, Date of decision on admissibility: 26 March 1990.

Rastorgueva v. Poland, no. 1517/2006, Date of adoption of views: 28 March 2011.

Samuel Lichtensztejn v. Uruguay, no. 77/1980, Date of adoption of views: 15 July 1999.

Susila Malani Dahanayake and 41 other Sri Lankan Citizens v. Sri Lanka, no. 1331/2004, Date of decision on admissibility: 25 July 2006.

Wdowiak v. Poland, no. 1446/2006, Date of decision on admissibility: 31 October 2006.

\section{SUMMARY}

\section{Individual Communications Against Poland}

Before the Human Rights Committee: a Review and Tentative Conclusions

Poland has been a party to the International Covenant on Civil and Political Rights of 16 December 1966 for forty years, and has been recognizing the right of individuals to submit applications to the Human Rights Committee for 25 years. The total number of 
78 | Adam Mickiewicz University Law Review

communications amounts to 11 , and the results of the examination thereof encourage consideration of denouncing the Optional Protocol to the International Covenant on Civil and Political Rights of 16 December 1966.

Keywords: Human Rights Committee, the International Covenant on Civil and Political Rights, public international law

Katarzyna Easak, University of Gdańsk, Faculty of Law and Administration, Bażyńskiego 6, Gdańsk 80-309, Republic of Poland, e-mail: katarzyna.lasak@prawo.ug.edu.pl. 